\title{
The International Exchange of Students: Problems and Solutions at the Riga Technical University
}

\author{
Janis Strauhmanis \\ Riga Technical University, Latvia \\ strauhmanis bf.rtu.lv
}

Keywords: exchange of students, foreign languages, coursebooks

\begin{abstract}
Summary
The international exchange of students plays an important role in acquisition of new knowledge and skills. However, it was possible to start implementing such exchange programmes at the Riga Technical University only in 1991 after the reestablishment of the Department of Geodesy. Currently, the Riga Technical University cooperates with several countries in implementing exchange programmes of students. The main problems encountered in this process are similar: inadequate foreign language skills, a lack of internationally recognized coursebooks and other study materials, insufficient cooperation between the universities that implement exchange programmes. These problems should be addressed by creating a working group and expanding cooperation, as well as enhancing requirements for students who participate in the exchange programmes.
\end{abstract}

\section{The present situation}

The first foreign students who came to study geodesy at the Riga Technical University (RTU) in 1994 were from Lebanon, however, their basic field of study was civil engineering. A year later the students of RTU went to Finland and Sweden to study at the Technical University of Helsinki and the Higher Technical School of Stockholm. From 1998 to 2004, several citizens of Lebanon mastered the study programme in geodesy and cartography at the Riga Technical University and defended their engineering projects.

The students of RTU went to study (mostly for one semester) to the following countries:

- Denmark: University of Aalborg, Technical University of Denmark,

- Finland: Mikkeli Politechnic,

- Germany: High Technical School of Karlsruhe, High Technical School of Stuttgart, 
- Spain: University of Valencia.

The following figures characterize the exchange programme of students in geodesy and cartography:

- in 1995/96 and 1996/97 four students from RTU studied abroad;

- in 1998/99 and 1999/2000 four students from Lebanon studied at RTU and five students of the Department of Geomatics studied abroad;

- in 2000/01 and 2001/02 the Lebanese students continued their studies at RTU and three students of the Department of Geomatics studied abroad;

- in 2003/04 the Lebanese students completed their studies at RTU and three students of the our Department went to study in Germany and Finland.

During the following year a comparatively small number of students from the Department of Geomatics, RTU studied abroad. In 2006/07 four our students went to Finland to study at the Mikkeli Politechnic (Finland), one student went to Germany - High Technical School of Stuttgart and one to University of Valencia (Spain). 4 students from Spain (University of Valencia), two from Germany and France studied at the Department of Geomatics, RTU.

It should be noted that the number of foreign students studying in Latvia and also at the Riga Technical University has recently increased: in the academic year 2006/2007 1425 students from 57 countries studied at Latvian higher educational establishments, but at RTU -76 students from 30 countries. 829 students from 25 Latvian higher educational establishments are now studying abroad; 67 students of the Riga Technical University are now studying in 20 foreign countries.

\section{Problems and solutions}

Having been involved in the international exchange of students for more than ten years, we can identify the main problems; some of them, in our opinion, are the following:

- inadequate English language skills;

- a lack of internationally recognized coursebooks and other studies materials in geodesy, surveying and cartography;

- some higher educational establishments that offer exchange programmes do not provide instruction in English for foreign students.

In our opinion, the above-mentioned problems could be solved in the following way:

- the students who want to go to study in another country should pass a foreign language test that proves their ability to master courses in their speciality in the required foreign language;

- before implementing an exchange of students, the relevant universities should exchange information about the previously acquired knowledge and the required subjects, as it 
was already pointed out in the plan drawn up by the FIG 2nd commission and, in our opinion, it should be dealt with immediately;

- it is necessary to hold a seminar at international level to discuss the issues of implementing student exchange programmes. Proposals about a new coursebook in cartography were made at FIG Congress.

It should be noted that we closely cooperate with our Finnish colleagues in exchanging information, which makes it possible for us to improve the training of foreign students. The International Institute for Geo-Information Science and Earth Observation (ITC) has great experience in training foreign students and they consider that one of the main problems in working with groups of foreign students is their different level of basic knowledge. This problem is encountered quite often.

The Department of Geomatics of Riga Technical University is ready to participate in finding solutions to the above-mentioned problems.

\section{References}

1. Balodis J., Strauhmanis J., Tarasenko M. System of cartographic and GIS study subjects at the Department of Geomatics, Riga Technical University. Proceedings: 1st International conference on Cartography \& GIS. Borovetz, 2006.

2. Bruijn de S.. Knowledge Economy for Whom? Task for Europe in Internationalisation of Education. GEO Informatics, July/August, 2006., p.32 - 35.

3. FIG Commission 2. Draft Work Plan 2007 - 2010. Munich, 2006.

4. Dasse G. Enhancing the Representation of Under-Represented Groups in FIG. FIG publication No.35, Copenhagen 2006.

5. Magel H. 2005, New Challenges to Education in Geodesy and Geoinformation. GEOinformatics, April/May 2005., p. 12 - 13.

6. Quality Assurance in Surveying Education. (1999) FIG Publication No.19.

7. Strauhmanis J. Geomatics Education in Latvia. GIM International, March 2007.,

8. Strauhmanis J. Activities of the state and private cartography in Latvia. East and Central Europe experience in cartography of new economy and political systems.Legal and organizational problems. Abstracts. Wroclaw-Polanica Zdroj, 2006. p. 56-57.

9. Quality Assurance in Surveying Education. (1999) FIG Publication No.19. 
